\title{
URGENSI PERUBAHAN POLA PIKIR DALAM MEMBANGUN PENDIDIKAN BERMUTU
}

\author{
Denny Kodrat ${ }^{1 *}$ \\ 1Program Studi Sastra Inggris, Sekolah Tinggi Bahasa Asing (STBA) Sebelas April, Sumedang, Indonesia
}

\section{ARTICLE INFO}

\section{Keywords}

Mindset, Pendidikan Islam,

Penjaminan Mutu, Pola Pikir

\section{*Correspondence denny.kodrat@gmail.com}

\section{Article History}

Received 24 November 2018

Accepted 21 January 2019

Published online 28 January 2019

\section{ABSTRACT}

Harapan untuk menghasilkan keluaran yang bermutu sesuai dengan keinginan masyarakat merupakan dambaan semua pihak. Institusi pendidikan seiring dengan tantangan dan persaingan global berlomba untuk memberikan nilai tambah dari lulusan yang dibinanya dan memberikan pengaruh positif (outcome) terhadap kemajuan peradaban masyarakat. Berturut-turut pendidikan Indonesia belum dapat berbicara banyak dalam kompetisi regional dan internasional sebagaimana rilis PISA. Begitu pula guru sebagai ujung tombak dalam pelayanan pendidikan dipandang belum memiliki kompetensi yang memadai untuk memberikan pelayanan pembelajaran yang sesuai dengan tuntutan jaman. Pengguliran konsep pendidikan abad 21 dipandang menjadi jalan keluar (way out) dalam mengakomodasi potensi pembelajar yang adaptif dengan perubahan dan digital. Keterampilan dalam berpikir kritis, kolaborasi serta penajaman kemampuan literasi diharapkan mampu meningkatkan mutu pendidikan. Tentu saja perubahan pola pikir (mindset) terhadap hakikat pendidikan menjadi prasyarat mutlak dalam upaya menghadirkan pendidikan bermutu di tengah masyarakat.

Hope for creating a qualified outcome which meets people need is every person expectation. Educational institution in the era of global competition attempts to give added values and positive outcome towards its graduation in enhancing civilization. Education of Indonesia has not got achievement in regional and international competition as PISA released. At the same time, a teacher as a front liner in giving educational service is regarded not to have an adequate qualification in up to date teaching activity. The concept of education in the 21 century is considered as a way out in accommodating a learner which is adaptive with a change and digital. Skills in critical thinking, collaboration, and shaping literacy competence are expected to improve the quality of education. The change of mindset towards the nature of education is an important requirement in presenting a good education in society.

\section{PENDAHULUAN}

Revolusi industri 4.0 sejatinya mengubah paradigma pendidikan yang hanya berpikir secara materialis. Pendidikan yang saat ini menjadi human capital investment dianggap akan memberikan keuntungan materi saat seseorang lulus dari setiap jenjangnya (return to education) akhirnya membentuk pola berpikir kapitalistik. Sisi humanisme yang mendorong pada kepedulian (care), kesantunan (good manner), para lulusan seakan dikalahkan oleh indeks prestasi kumulatif, label perguruan tinggi (negeri atau swasta) serta tentunya masa tunggu lulusan, daya serap lulusan oleh dunia industri dan usaha. Padahal inti dari pendidikan adalah

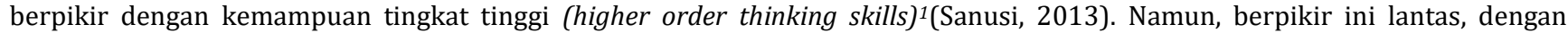
dibenturkan pada realitas jaman, tidak membawa kepada puncak berpikir (kebijaksanaan/wisdom), melainkan disesuaikan dengan keberterimaan pasar. Amanah Undang-undang No. 20 Tahun 2003 tentang Sistem Pendidikan Nasional menekankan peningkatan "keimanan dan ketakwaan kepada Tuhan Yang Maha Esa serta akhlak mulia dalam rangka mencerdaskan kehidupan

\footnotetext{
${ }_{1}^{1}$ Higher Thinking Order Skills disingkat (HOTS) menjadi fokus dalam kurikulum 2013 saat ini, yaitu kemampuan berpikir siswa pada level analisis, evaluasi dan kreasi sesuai taksonomi Anderson yang merevisi taksonomi Bloom. Sementara level mengingat, memahami dan aplikasi digolongkan sebagai Low Thinking Order Skills (LOTS)
} 
bangsa" sebagai tujuan pendidikan. Arah tujuan ini, mengalami degradasi makna dan tergerus oleh pragmatisme kebutuhan pasar. Iman takwa serta akhlak mulia secara realitas dikalahkan oleh kompetensi lulusan berdasarkan kebutuhan pasar.

Pendidikan (formal) masih menyentuh 50 persen penduduk Indonesia ${ }^{2}$, artinya terdapat 50 persen penduduk Indonesia yang tidak didik oleh negara dalam pendidikan formal dengan berbagai macam latar belakang alasan. Bila yang mengikuti sistem pendidikan pun belum mendapat jaminan memiliki kemampuan afeksi yang diharapkan-termasuk dalam hal ini iman, takwa serta akhlak mulia, apalagi penduduk Indonesia yang tidak berkesempatan mengenyam bangku pendidikan. Padahal, pendidikan adalah salah satu pilar utama dalam pembentukan peradaban manusia. Bahkan Che Guevara menyatakan bahwa untuk mendapatkan hak pendidikan meski harus dengan jalan revolusi dengan ungkapan terkenalnya, "Ifyou want an education, join the revolution"3 (Jika anda ingin pendidikan, maka bergabunglah dalam revolusi). Pernyataan itu seolah-olah menunjukkan bahwa pendidikan adalah modal dasar dan utama bagi manusia baik secara individu maupun kolektif untuk melangsungkan kehidupan yang lebih baik. Berkaitan dengan hal itu, dalam konteks ini, "memanusiakan manusia muda" (Driyarkara, 1980) dapat dipahami sebagai fungsi pendidikan untuk senantiasa menjaga pola berpikir dan bersikap manusia untuk selalu muda. Muda dalam spirit, muda dalam pembaharuan dan muda dalam memimpin. Dalam pepatah Barat disebut "Keep the leader young". Pendidikan menjaga agar semangat untuk berbuat baik selalu dipelihara dan diwariskan dari satu generasi kepada genarasi lain. Oleh karenanya, kebutuhan terhadap pendidikan tidaklah ditujukan untuk kehidupan masa depan atau nanti (Crow dan Crow, 1960), melainkan untuk saat ini, saat nanti dan tentunya bagi seorang muslim, untuk Hari Kemudian (The Day of Judgment).

Dalam keyakinan muslim, pendidikan menghantarkan pada jati diri muslim yang unggul dan paripurna, yaitu pembentukkan kepribadian Islam (as-syakhsiyyah Islamiyyah) yang mensyaratkan terbentuknya pola berpikir dan pola sikap yang merujuk pada hukum syara'. Dalam Islam, pendidikan tidak berbicara pada level keterserapan lulusan an sich, kebutuhan dunia industri dan usaha, atau menjadi penghidupan dunia, melainkan bagaimana lulusan dapat menghadapi segala macam tantangan dan problematika kehidupan dengan kacamata Islam. Lebih jauh, prinsip halal dan haram menjadi kendali bagi lulusan untuk tidak terjebak pada prinsip menghalalkan segala macam cara (the end justifies a mean) untuk menghadapkan pekerjaan dan penghidupan. Untuk membentuk output yang berjati diri tersebut, tentunya disyaratkan adanya perubahan pola pikir pada stakeholders pendidikan.

\section{PERUBAHAN MINDSET}

\subsection{Sistem Input-Proses-Output-Outcome}

Pengelolaan pendidikan secara umum dapat digambarkan melalui Gambar 1 di bawah ini:

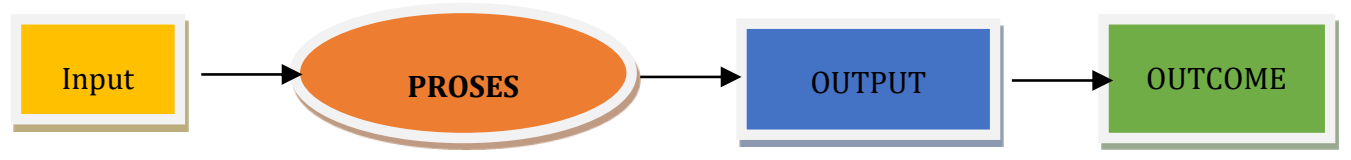

Gambar 1. Alur Sistem Mikro Pendidikan

Dalam pendidikan, secara sederhana dapat digambarkan bahwa peserta didik sebagai input mengalami proses interaksi dengan tenaga pendidik, tenaga kependidikan, kurikulum, bahan ajar termasuk di dalamnya fasilitas yang memadai dalam proses interaksi tersebut. Setelah peserta didik menyelesaikan proses pembelajaran dan dinyatakan lulus, maka berikutnya ia akan memberikan pengaruh kepada masyarakat (outcome). Seluruh sistem pendidikan di manapun mengacu kepada alur sistem mikro pendidikan ini. Adapun yang membedakan sistem tersebut adalah sistem nilai (value system) yang ditanamkan dalam domain proses. Sistem nilai ini mengikuti arah kebijakan pemerintah seperti kurikulum yang ditetapkan. Kurikulum sendiri merupakan produk politik yang mempengaruhi output dan outcome peserta didik.

Tujuan pendidikan nasional adalah meningkatkan keimanan, ketakwaan serta akhlak mulia peserta didik, maka arah proses pembelajaran ditujukan untuk ketercapaian tujuan tersebut. Bila masih terjadi anggapan bahwa ijazah, kompetensi lulusan dan daya serap pasar lebih penting dari iman, takwa dan akhlak mulia, atau menganggap tujuan pendidikan tersebut hanyalah formalitas, maka terjadi kesalahan dalam berpikir. Hal ini disebabkan tujuan menjadi target yang harus dicapai dan menjadi ultimate purpose (target tertinggi) yang harus melekat secara inheren atas lulusan. Sikap tersebut selalu ada saat lulusan sudah lama meninggalkan kampus tempat ia belajar. Walhasil, bila korupsi, suap dan perbuatan yang bertentangan dengan iman, takwa dan akhlak mulia ini masih terjadi, maka proses pembelajaran yang terjadi belum mencerminkan proses yang berkesesuaian (in line with) dengan tujuan.

Berdasarkan pada Peraturan Pemerintah No. 19 Tahun 2005 dengan beberapa kali perubahan hingga yang terakhir PP. No. 13 Tahun 2015 tentang Standar Nasional Pendidikan, pemerintah sebagai salah satu stakeholder pendidikan, berupaya membuat standar minimal pendidikan yang wajib dipenuhi seluruh unit kerja pendidikan dari Aceh hingga Papua. Begitu pula dengan pendidikan tinggi. Diterbitkan Permenristek Dikti no. 44 Tahun 2015 tentang Standar Nasional Pendidikan Tinggi, selain untuk mempertajam keberadaan Kerangka Kualifikasi Nasional Indonesia (KKNI) ${ }^{4}$ sebagai cara untuk meningkatkan daya saing lulusan juga untuk menstandarkan seluruh proses pendidikan di wilayah Indonesia. Sehingga diharapkan, kualitas lulusan perguruan tinggi tidak berbeda jauh antara satu dengan yang lain.

Kembali pada pembahasan tujuan pendidikan nasional sebagaimana diatur dalam Undang-undang No. 20 Tahun 2003, upaya mewujudkan iman, takwa dan akhlak mulia ini dalam tataran praksis belum nampak terepresentasi dalam struktur kurikulum, terkecuali bahwa tujuan yang hendak dicapai adalah dunia kerja. Hal ini bisa dilihat dari bobot mata pelajaran/kuliah yang hanya memberikan porsi terbatas kepada pengajaran agama. Meski beberapa lembaga pendidikan berupaya mengintegrasikan pelajaran

\footnotetext{
2 Data UNICEF tahun 2016 menunjukkan 2.5 juta anak Indonesia tidak dapat melanjutkan pendidikan lanjutan

3 Walker,1981:120

${ }^{4}$ Kerangka Kualifikasi Nasional Indonesia adalah penjenjangan kualifikasi sumber daya manusia Indonesia yang menyandingkan, menyetarakan dan mengintegrasikan sektor pendidikan dengan sektor pelatihan dan pengalaman kerja dalam suatu skema pengakuan kemampuan kerja yang disesuaikan dengan struktur di berbagai sektor pekerjaan.
} 
agama kepada seluruh mata pelajaran/kuliah, namun kembali kepada pola pikir stakeholder ${ }^{5}$ pendidikan yang menganggap hardskills ${ }^{6}$ lebih penting daripada softskill7s. Sebagaimana pula pemimpin sekolah lebih memperhatikan pembangunan fisik daripada proses pembelajaran di dalam kelas. Orang tua pun lebih bangga bila anaknya menjuarai olimpiade nasional atau internasional tanpa menganggap penting budi pekertinya. Sementara itu, sekolah/kampus pun nampaknya jarang mengevaluasi sejauhmana ketercapaian kompetensi lulusan yang sesuai dengan visi dan misi sekolah/kampus. Padahal visi sekolah/kampus menjadi keyakinan dan semangat untuk membentuk para lulusan. Bila visi dan misi sekolah/kampus menghadirkan semangat religiusitas, spiritualitas dan ketakwaan sebagai ciri utama sekolah/kampusnya, maka tentunya, ciri tersebut harus melekat erat pada para lulusannya. Sekolah yang bermutu adalah saat ia mampu mewujudkan ciri pada visi sekolah/kampus pada para lulusannya. Bukan sekadar para lulusannya cepat bekerja, menjadi karyawan perusahaan nasional atau internasional, melainkan lulusan yang memiliki prinsip dan cara pandang yang terpancar dari keimanan dan ketakwaannya. Pola pikir seperti ini perlu dimiliki bukan saja oleh pihak sekolah/kampus, melainkan oleh masyarakat dan negara. Pemerintah, stakeholder, dan masyarakat memiliki tanggung jawab kolektif, tentunya dipimpin oleh pemerintah, untuk mengubah cara pandang masyarakat dan stakeholder pendidikan lainnya bahwa pendidikan tidak saja hanya dipahami dengan mengajarkan masalah ilmu pengetahuan dan teknologi, namun lebih dari itu sebagaimana yang dikatakan Prof. Dr. M. Nuh ${ }^{8}$ bahwa pendidikan adalah satu-satunya senjata untuk memerangi kemiskinan dan keterbelakangan peradaban, maka ia harus diarahkan pada pembentukan aspek religiusitas. Dengan paradigma seperti ini, pemahaman sekulerisme ${ }^{9}$ (pemisahan agama dari kehidupan) tidak memiliki ruang bebas untuk masuk dalam pola berpikir peserta didik dan juga para pendidiknya. Seluruh ilmu pengetahuan yang diajarkan, proses pembelajaran dan pengelolaan pendidikan menghadirkan aspek religiusitas dalam pelaksanaannya. Sehingga, terjadi perubahan pola pikir dalam keseluruhan proses tersebut dari pemicu reward ${ }^{10}$ dan punishment ${ }^{11}$ yang berorientasi materi menjadi aspek transendental ${ }^{12}$.

\subsection{Paradigma Mutu}

Pendidikan bermutu menjadi idaman masyarakat. Mereka mencari sekolah yang dapat menjamin anak-anak mereka menjadi lulusan yang berkualitas. Namun yang menjadi dilema, masyarakat cenderung melihat mutu secara permukaan (surface), seperti gedung yang megah, fasilitas yang lengkap, atau lulusan yang cepat bekerja. Tidak masuk pada ranah substantif mutu, Setidaknya saat ditanya tentang hakikat mutu, masyarakat tidak mampu memaparkannya. Adapun mutu secara substantif adalah seberapa mampu pengelola pendidikan memuaskan pelanggan (customer)13 bahkan melebihi apa yang mereka harapkan (Salis, 2002). Dalam konteks ini, masyarakat sebaiknya mampu memetakan apa yang mereka butuhkan dari pendidikan yang mereka pilih. Sehingga hasil pendidikan benar-benar dapat mereka manfaatkan. Dalam setting masyarakat kapitalisme, kebutuhan diidentikan dengan peluang kerja. Sehingga terjadilah hukum supply dan demand, sekolah yang dianggap memberikan akses pada peluang kerja tersebut akan menyeleksi calon peserta didik secara ketat dan tidak menutup kemungkinan mematok biaya pendidikan yang lebih tinggi dibanding sekolah yang tidak demikian. Masyarakat melabeli sekolah tersebut dengan sebutan favorit. Sementara itu, sekolah yang dianggap tidak favorit, akan mencari calon peserta didik dan tentunya dengan biaya yang lebih rendah.

Pemerintah membuat regulasi mengenai penjaminan mutu pendidikan tinggi dengan dirilisnya Peraturan Menteri Riset dan Pendidikan Tinggi No. 62 Tahun 2016. Salah satu tujuannya adalah agar perguruan tinggi memiliki kepedulian (concern) terhadap mutu dengan diterapkannya sistem penjaminan mutu. Secara luas, pemerintah ingin memeratakan mutu pendidikan dari Sabang hingga Merauke. Namun upaya ini belum mampu mengubah mindset masyarakat terhadap mutu pendidikan, diantaranya pilihan studi yang menitikberatkan pada ketersedian pasar, cepat bekerja dan hidup mapan. Seolah-olah pendidikan hanya dimaknai terhadap pemenuhan kebutuhan duniawi saja, tidak berpikir jauh daripada itu. Termasuk dalam pemahaman terhadap adab14. Bila dalam tradisi keilmuan Islam, adab diletakkan sebelum ilmu, maka pendidikan saat ini nampaknya berbeda. Ilmu diposisikan lebih penting daripada adab. Sehingga para lulusan terkadang tidak menjadikan sopan santun sebagai sesuatu yang penting dan menampel (built in) dalam sikap.

Perubahan mindset stakeholder pendidikan dalam konteks mutu menjadi sangat penting dilihat dari beberapa alasan, yaitu (1). Mutu perlu dipahami sebagai kebutuhan (need) dan sekaligus harapan masyarakat yang perlu dipenuhi secara maksimal. Pemenuhan atas kebutuhan tersebut mengindikasikan pendidikan tersebut telah bermutu; (2). Kebutuhan masyarakat terhadap pendidikan tidak boleh direduksi hanya dalam pemenuhan urusan duniawi (materi). Meski kebutuhan duniawi penting, namun penyiapan terhadap mental dan spiritual harus disimpan di bagian atas. Hal ini karena secara filosofis, pendidikan sejatinya adalah penyiapan manusia untuk menghadapi tantangan ke depan (Crow dan Crow, 1960). Tantangan ke depan ini, dalam konteks tujuan pendidikan nasional, dapat juga ditafsirkan sebagai kehidupan akhirat. (3). Kesadaran terhadap mutu tidak semata-mata tereduksi oleh kepentingan akreditasi an sich, mengejar predikat unggul BAN-PT namun menihilkan tujuan sejati mutu tersebut, yaitu akuntabilitas amanah pengelolaan pendidikan. Kesadaran mutu yang hakiki akan mempengaruhi cara berpikir masyarakat dalam melihat melihat fungsi pendidikan. Kepentingan sementara yang didapat dari hasil pendidikan, seperti pekerjaan, penghidupan duniawi, akan dibingkai dengan kepentingan jangka panjang, yaitu menghadirkan Allah Swt sebagai wujud penyembahan terhadap Sang Pencipta. Walhasil, para lulusan akan selalu ingat bahwa seluruh aktivitas yang dilakukan dalam bekerja, berkreasi, dan

\footnotetext{
5 Pemegang kepentingan dalam dunia pendidikan meliputi orang tua, masyarakat, dunia usaha dan industri, pemerintah.

${ }^{6}$ Kemampuan penguasaan ilmu pengetahuan, teknologi, sesuai dengan akademik atau disiplin ilmu yang dipelajari.

${ }^{7}$ Kemampuan interpersonal, non-akademik yang menunjang implementasi kemampuan disiplin ilmu yang dipelajari.

8 Mantan Menteri Pendidikan dan Kebudayaan pada era pemerintahan Presiden Soesilo Bambang Yudhoyono.

${ }^{9}$ Faham/ide yang melatarbelakangi ideologi kapitalisme yang pada abad pertengahan menjadi kebijakan politik yang disepakati masyarakat Eropa bahwa agama dan negara harus dipisahkan.

10 Dorongan untuk menyelesaikan kewajiban dengan motivasi pemberian penghargaan bila kewajiban tersebut dilaksanakan, bisa berbentuk promosi, nilai kinerja yang baik, akreditasi sekolah/kampus.

11 Dorongan untuk menyelesaikan kewajiban disebabkan kekhawatiran akan menerima sanksi, demosi, penurunan pangkat, nilai akreditasi atau kinerja sekolah/kampus.

${ }^{12}$ Aspek yang memiliki dimensi spiritual yang mendorong seseorang melakukan atau tidak melakukan sesuatu.

${ }^{13}$ Dalam konteks pendidikan, pelanggan (costumer) dipahami berbeda dengan dunia bisnis. Pelanggan adalah peserta didik, tenaga pendidik, masyarakat, pemerintah.

${ }^{14}$ Dikenal sebagai kesopanan, good manner yang muncul dari pemahaman dan penanaman nilai-nilai (values)
} 
berusaha senantiasa terikat dengan aturan dan ketentuan Allah Swt. Mindset yang melibatkan seluruh aktivitas dengan pencipta inilah yang seharusnya diwujudkan dalam proses pendidikan secara sistemik.

\section{PENDIDIKAN BERMUTU}

Sebagaimana yang diungkap pentingnya mengubah pola berpikir terhadap hakikat pendidikan untuk membangun pendidikan yang bermutu, maka langkah berikutnya yang perlu dilakukan dalam mengubah mindset, yaitu: (1). Mengubah pola pikir terhadap pembuat keputusan (decision maker) di level makro pendidikan, dalam hal ini dimulai pada tingkat menteri, pejabat setingkat eselon 1 baik pusat maupun daerah serta pejabat pelaksana. Pengubahan pola pikir tentang pendidikan ini sangat penting mengingat selama ini pada level pembuat keputusan, mindset yang dikembangkan adalah orientasi anggaran (budget oriented). Meski memang pertimbangan membuat kebijakan pendidikan dan struktur kurikulum melihat potensi tantangan luar, namun dalam tataran implementasi yang melibatkan birokrasi pendidikan, ruh atau spirit pembuatan kebijakan tereduksi oleh orientasi anggaran. Oleh karena itu, pembuatan regulasi pendidikan sebaiknya mampu mengubah pola pikir hingga level implementasi. Termasuk dalam hal ini pengubahan landasan filosofis pendidikan yang selama ini cenderung mengikuti filosofis dunia Barat yang cenderung sekuleris-materialis, sehingga tercermin dalam struktur kurikulum yang nampak tidak kompatibel dengan tujuan pendidikan nasional. Bagaimana mungkin membentuk generasi pelajar yang beriman, bertakwa dan berakhlak mulia bila upaya penanaman nilai-nilai tersebut hanya diberikan porsi dua jam pelajaran satu minggu untuk mata pelajaran pendidikan agama, atau dua sks untuk mata kuliah agama. (2). Perlu penerapan reward dan punishment yang konsisten pada level makro dan mikro pendidikan yang berkaitan dengan tata kelola pendidikan di level tersebut, termasuk pada proses rekrutmen dan pengawasan pengelola pendidikan. Reward dapat diberikan oleh pemerintah kepada pimpinan sekolah saat ia mampu mencapai bahkan melampaui visi yang ditetapkan. Sementara itu, punishment diberikan apabila ia tidak dapat mencapai visi tersebut. Selain itu, penguatan peran masyarakat dalam komite sekolah dalam memberikan saran dan pengawasan terhadap pengelola pendidikan. (3). Stakeholder pendidikan memberikan tantangan (challenge) terhadap pemimpin sekolah untuk membuat cetak biru (blue print) pengembangan sekolah yang hendak di capai. Cetak biru ini tidak seperti rencana strategi (renstra) sekolah yang berakhir pada tahap dokumen dan baru dibuka saat akreditasi sekolah dilakukan, melainkan menjadi sasaran pengembangan sekolah selama 510 tahun ke depan. Saat ini memang ada dokumen seperti Rencana Jangka Menengah dan Panjang (RJMP) sekolah, sebagai bagian dari renstra sekolah, namun "tradisi" dan kebiasaan yang menyebabkan dokumen strategis ini tidak menjadi acuan pengembangan sekolah, selain hanya seongok dokumen pelengkap sekolah. Oleh karena itu, penting sekali membentuk pola pikir stakeholder pendidikan untuk tidak hanya membuat banyak dokumen, namun juga menjadi acuan pengimplementasiannya. (4). Perlu ditanamkan pola pikir kepada seluruh sivitas akademika bahwa pendidikan adalah darah peradaban. Ia menjadi cara menyiapkan generasi untuk estafeta kepemimpinan. Tidak hanya untuk kepentingan dunia saja, namun juga untuk kepentingan akhirat. Penyiapan generasi yang shalih menjadi sangat penting. Penyiapan generasi ini perlu dimulai dengan penyamaan frekuensi visi dari seluruh stakeholders pendidikan. Tentunya, sistem yang selama ini menyuburkan nilai-nilai materialisme sekularistik dan sekaligus membuka celah korupsi, suap dan tindakan menyimpang lainnya perlu direvisi dan diubah. Perubahan ini harus dilakukan dengan sistem yang dapat menanamkan nilai-nilai spiritual yang di dalamnya terjadi pengawasan yang terikat dan terusmenerus sebagai manifestasi dari prinsip ihsan, yaitu ia meyakini bahwa Yang Maha Kuasa senantiasa mengawasinya tanpa jeda dan tanpa batas. Disaat yang sama, ia meyakini bahwa keseluruhan aktivitasnya akan dimintai pertanggungjawaban tidak hanya di dunia namun juga di akhirat. Sistem inilah yang akan melahirkan keshalihan sosial dimana nilai-nilai yang didapat dari ibadah ritualnya secara langsung diaplikasikan dalam kehidupan kesehariannya.

Oleh karenanya, pendidikan yang bermutu dapat dimaknai dengan tiga syarat yaitu: (1). institusi pendidikan dapat memuaskan kebutuhan pelanggan. Tidak dengan kepuasaan yang minimal (minimum satisfaction), namun melebihi dari apa yang dibutuhkan dan diharapkan (delight the customer). (2). Kebutuhan mendasar yang diharapkan oleh pelanggan (orang tua siswa, masyarakat) dari institusi pendidikan adalah mendidik dan membangkitkan kesadaran pada diri siswa/mahasiswa bahwa ia adalah makhluk yang harus tunduk, patuh serta taat kepada Sang PenciptaNya. Semakin tinggi seseorang mengenyam pendidikan, maka kebutuhannya adalah ia ingin lebih mengetahui dan lebih mengenal Sang Penciptanya. Tidak sebaliknya, semakin tinggi gelar yang didapat, semakin tinggi hati, rasional dan bahkan menentang aturan-aturanNya. (3). Dengan pendidikan yang ia dapatkan, maka ia menjadi manusia dan warga Negara yang baik. Tidak menjadi beban masyarakat. Ia mampu mengimplementasikan ilmu yang ia dapatkan. Pendidikan pun memberikan dampak pada perubahan sikap dan pola pikirnya. Bila tiga syarat ini dapat dipenuhi oleh institusi pendidikan, maka ia dapat disebut institusi pendidikan yang bermutu, meski outputnya tidak banyak yang diterima di sekolah-sekolah lanjutan bergengsi atau mereka tidak terserap di dunia kerja, malah ia membuka lahan pekerjaan.

Pendidikan bermutu tidak selalu diidentikkan dengan biaya mahal. Pembiayaan pendidikan dapat mengikuti delapan standar nasional pendidikan yang sudah ditetapkan pemerintah dan disesuaikan dengan kebutuhan. Hal ini disebabkan pendidikan sejatinya bukanlah bisnis komersil, melainkan nirlaba. Sehingga Setiap sisa uang dikembalikan lagi pada operasional pendidikan. Selain itu, pendidikan bermutu pada dasarnya diarahkan oleh pola pikir. Perubahan pola pikir menjadi syarat utama dalam merespon tantangan dan mengubah tantangan menjadi peluang. Terlebih tantangan nyata saat ini adalah revolusi industry 4.0. Covey (2010) menyebutkan bila perubahan pola pikir akan mengakibatkan perubahan yang besar dan mendasar. Perubahan pola pikir sivitas akademika adalah bagaimana menjadikan mutu sebagai budaya organisasi dan individunya (corporate and individual culture). Hal ini tidak akan dapat terwujud bila paradigma yang digunakan oleh sivitas akademika adalah paradigma yang kuno dan kolot, melainkan harus diubah kepada paradigma baru (obsolete). Paradigma baru yang harus dibangun dalam meningkatkan mutu sebagaimana yang disarankan Natawidjaja (2005) adalah sebagai berikut: (1). Quality First. Seluruh pikiran dan tindakan pimpinan sekolah tinggi pada berbagai tingkat organisasi dan unit harus memprioritaskan mutu; (2). Stakeholder-in. Seluruh pikiran dan tindakan pimpinan sekolah tinggi pada berbagai tingkat organisasi harus ditujukan pada kepuasan stakeholders; (3). The Next Process is Our Stakeholders. Setiap orang yang melaksanakan tugas di sekolah tinggi dalam penyelenggaraan proses pendidikan harus menganggap pihak lain yang menggunakan hasil pelaksanaan tugasnya sebagai stakeholders-nya yang harus dipuaskan. (4). Speak With Data. Setiap orang yang menyelenggarakan proses pendidikan di sekolah tinggi dalam melakukan tindakan dan pengambilan keputusan harus didasarkan pada hasil analisa yang relevan; (5). Upstream Management. Seluruh pengambilan keputusan dalam penyelenggaraan proses pendidikan di sekolah tinggi dilakukan secara partisipatif.

Deming (dalam Salis, 2002) menjelaskan bahwa untuk menghasilkan mutu pendidikan yang tinggi memerlukan persiapan yang baik dan terencana seperti proses merancang, proses penyusunan perencanaan, proses manufacturing dengan mengurangi 
pemborosan anggaran dan kesalahan produksi. Kualitas perencanaan yang baik harus mencakup perubahan normatif dan nilai dalam pengelolaan organisasi, indentifikasi pelanggan, pengembangan produk yang bermutu tinggi, pengembangan proses yang lebih efektif dan efisien, dan tentunya ditopang oleh paradigma yang kuat tentang mutu oleh sivitas akademikanya. Mutu dipahami sebagai kebutuhan yang harus dilaksanakan. Ia tidak akan berjalan secara normal bila setiap aktivitas terlepas dari orientasi mutu. Bisa digambarkan secara sederhana bahwa mutu dalam proses pendidikan ibarat ikan dengan air laut. Ia tidak dapat berkembang dan tumbuh bila dipisahkan dari komunitas dan lingkungan air laut. Kesadaran terhadap mutu ini tidaklah hanya terletak pada bagian yang berkaitan langsung dengan persoalan mutu seperti pimpinan unit pendidikan atau departemen penjaminan mutu. Kesadaran mutu ini harus terdistribusi secara merata kepada seluruh sivitas akademika, sehingga pada akhirnya mutu akan melekat erat (embedded) dalam setiap proses yang dijalankan. Bila sudah demikian, maka ia dapat diibaratkan seperti air laut dengan asinnya. Tidak akan pernah terlepas.

Arcaro (2007) lebih jauh menggambarkan proses pengembangan mutu sebagaimana dapat dilihat dari diagram berikut ini:

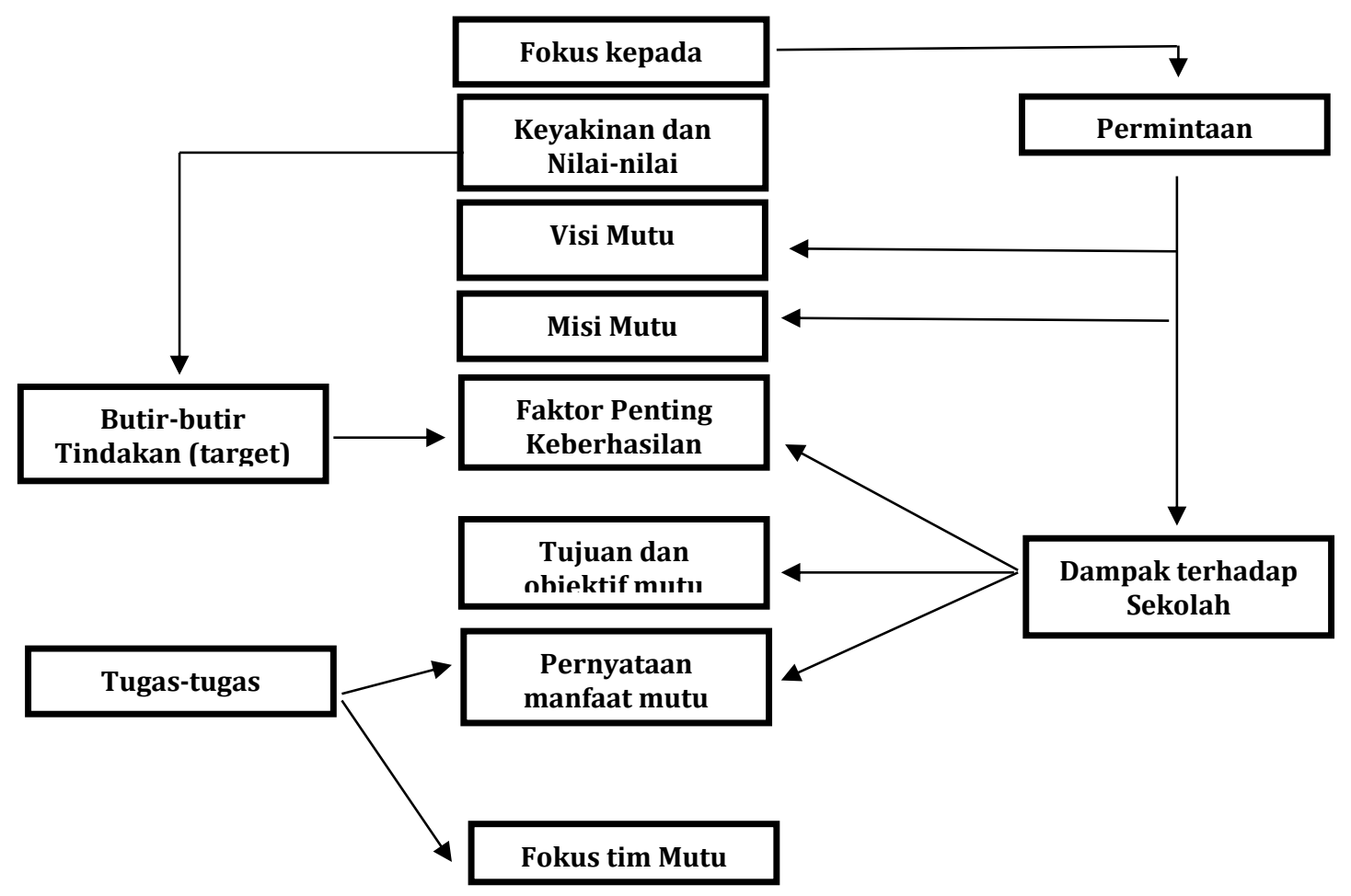

Gambar 2. Diagram Pengembangan Mutu (Arcaro, 2007)

Pada gambar 2 di atas, prinsip fokus kepada pelanggan (customer) mendorong lembaga pendidikan untuk mengikuti setiap permintaan kebutuhan pelanggannya. Setiap saran dan complain akan langsung ditindaklanjuti. Selain itu, sekolah menetapkan dan memiliki apa yang disebut sebagai nilai-nilai universitas/sekolah (university/school values) yang diyakini dan dijalankan. Visi dan misi yang berorientasi pada mutu mengakomodasi saran dan masukan dari pelanggan. Sekolah akan memiliki dampak (outcome) terhadap masyarakat dan eksistensi dirinya bila ia mampu menjalankan faktor penting keberhasilan mutu, memiliki tujuan mutu serta pernyataan manfaat mutu. Seluruh sivitas akademika menjalan tugas pokok dan fungsinya berdasarkan pernyataan mutu dan senantiasa melakukan pengelolaan mutu secara berkelanjutan (sustainable) dan di evaluasi secara berkala.

\section{KESIMPULAN}

Proses perubahan pola pikir meski terlihat sederhana, sebenarnya membutuhkan waktu yang panjang, bergantung seberapa dalam pola pikir lama ada bersemayam dalam mindset seluruh sivitas akademika dan stakeholder pendidikan. Bila pola pikir sudah lama terpapar oleh cara pandang yang materialistik dan sekuler, maka membutuhkan waktu yang cukup panjang untuk menggantikannya. Salah satu indikator telah berubahnya cara berpikir masyarakat dalam melihat pendidikan adalah saat mereka mulai memperhatikan aspek spiritual sebagai prioritas pertama dalam perkembangan anak-anaknya, lalu diikuti oleh kompetensi yang dibutuhkan. Demikian halnya, saat masyarakat mulai mencoba menerobos pendidikan formal dengan melirik kepada pendidikan luar sekolah untuk menambah ilmu agama bagi anaknya, atau menyekolahkan mereka pada sekolah sore untuk pendidikan agamanya, maka sejatinya ini adalah kebutuhan yang secara cepat, seharusnya, ditangani oleh pemerintah dengan melihat kembali arah dan struktur kurikulum, serta sudah memadaikah kurikulum dan proses pembelajaran di sekolah dalam menghadapi tantangan revolusi 4.0 ini. Tentunya, pola pikir mengenai pentingnya pembentukan kepribadian manusia sebagai tujuan hakiki pendidikan seharusnya disosialisasikan juga kepada masyarakat, sehingga tuntutan masyarakat tidak bersifat pragmatis dalam menuntut sekolah untuk mendidiknya anak-anaknya. Tuntutan agar anak-anaknya mencapai apa yang dicitacitakannya, baik itu profesi atau sekolah lanjutan, disampaikan kepada sekolah tanpa menghilangkan tuntutan dasar yang seharusnya juga tidak lupa diminta kepada sekolah yaitu tuntutan agar anak-anaknya mampu mengenal Tuhannya secara baik dan patuh. Aspek ini tentu saja sangat sejalan dengan revolusi 4.0 yang saat ini dijadikan tantangan untuk dihadapi oleh dunia pendidikan.

\section{Referensi}

Arcaro, J. (2007). Pendidikan Berbasis Mutu. Jogjakarta: Pustaka Pelajar.

Covey, S. (2010). Tujuh Kebiasaan Manusia Yang Efektif. Jakarta: Bina Rupa Aksara. 
Crown, \& Crow. (1960). An Introduction to Education in Educational Administration. New York: Oxford University Press. Driyarkara. (1980). Tentang Pendidikan. Jakarta: Yayasan Kanisius.

Salis, E. (2002). Total Quality Management in Education. London: Kogan Page.

Sanusi, A. (2013). Kepemimpinan Pendidikan: Strategi Pembaruan, Semangat Pengabdian, Manajemen Modern. Bandung: Penerbit Nuansa Cendekia.

Peraturan Pemerintah No. 13 Tahun 2015 Tentang Perubahan Kedua atas PP No. 19 Tahun 2005 Tentang Standar Nasional Pendidikan

Undang-Undang Republik Indonesia No. 20 Tahun 2003 Tentang Sistem Pendidikan Nasional.

Walker, J. (1981). The End of Dialogue: Paulo Freire on Politics and Education. In R. MacKie (Ed.), Literacy and Revolution: the Pedagogy of Paulo Freire. New York: Continuum. 